\title{
Interpretasi Salt Water-Fresh Water Zone menggunakan Metode Geolistrik Resistivitas Konfigurasi Wenner-Schlumberger di Desa Majasto dan Ponowaren, Kecamatan Tawangsari, Kabupaten Sukoharjo
}

\author{
Adha Nur Hidayat, ${ }^{*}$ Darsono, dan Darmanto \\ Jurusan Fisika, FMIPA-Universitas Sebelas Maret \\ Jl. Ir. Sutami No 36 A Surakarta 57126
}

\begin{abstract}
Intisari
Penelitian mengenai interpretasi salt water-fresh water zone menggunakan metode geolistrik resistivitas konfigurasi Wenner-Schlumberger telah dilakukan di Desa Majasto dan Desa Ponowaren, Kecamatan Tawangsari, Kabupaten Sukoharjo. Daerah tersebut terdapat salt water yang mencemari sumur warga. Pengukuran dilakukan dengan menggunakan alat Resistivitymeter OYO model 2119C McOHM-EL. Langkah awal dilakukan survei pendahuluan dengan mencari daya hantar listrik (DHL) dan kedalaman sumur warga yang dijadikan sampel, hasil dari data itu lalu diolah dengan software Surfer 11 sehingga diperoleh mapping data Salt Water-Fresh Water. Tahap selanjutnya mencari data resistivitas semu, data yang diperoleh kemudian diolah menggunakan softwere Res2Dinv untuk penampang 2 dimensi dan software Rockwork hasil interpretasi 3 dimensi secara keseluruhan. Batas antara Salt Water-Fresh Water diprediksi pada lintasan ketiga dengan bentang 1500 meter dan kedalaman 38,8 meter.
\end{abstract}

\begin{abstract}
Research on interpretation of the salt water-fresh water zone using geoelectric resistivity Wenner-Schlumberger array has been conducted in Majasto village and Ponowaren village, Tawangsari District, Sukoharjo Regency. In These areas the well are contaminated by salt water. Measurements were performed using an Resistivitymeter OYO McOHM-EL 2119C models. The initial step conducted a preliminary survey to search for electrical conductivity (EC) with the depth of the wells as the sample, the results of the data were then processed with the software Surfer 11 to obtain the mapping of salt water-fresh water data. The next step was obtaining apparent resistivity data, the data obtained were processed using Res2Dinv software to 2 dimensional cross section model and Rockworks software showed 3 dimensional of the whole lines. Limitation between salt water-fresh water zone is predicted on the third line with position 1500 meters and a depth of 38.8 meters.
\end{abstract}

KATA KUNCI: salt water, fresh water, Wenner-Schlumberger array, resistivity

\section{PENDAHULUAN}

Air tawar merupakan kebutuhan yang sangat diperlukan bagi kehidupan manusia. Pemanfaatannya sangatlah banyak antara lain untuk masak, minum, mencuci, mandi. Air tawar merupakan air yang tidak berasa, berbau, dan berwarna. Berdasarkan survei pendahuluan yang telah dilakukan di Desa Majasto dan Desa Ponowaren, Kecamatan Tawangsari, Kabupaten Sukoharjo sebagian sumur warga desa sudah tidak layak digunakan dikarenakan air sumur tersebut terdeteksi salt water. Sekitar tahun 2010 telah dibangun instalasi Perusahaan

*E-MAIL: adhanurhidayategmail.com
Daerah Air Minum (PDAM) di desa tersebut tepatnya di belakang SD Ponowaren 1 (sebelah selatan Desa Majasto) [1].

Untuk mengetahui pemetaan dan persebaran zona air asin dan air tawardi daerah tersebut maka perlu dilakukan survei geofisika. Salah satu metode yang dapat digunakan untuk mengetahui struktur bawah permukaan bumi adalah metode geolistrik. Metode geolistrik merupakan metode yang digunakan untuk pendugaan struktur bawah permukaan bumi berdasarkan pada resistivitas atau tahanan jenis batuan penyusun bumi [2].

Wilayah di eks-karesidenan Surakarta memiliki sumber daya air yang potensial, hal ini dikarenakan terletak pada intermountain basin (daerah cekungan antara beberapa gunung) yang menerima suplai air berupa airtanah atau mata air dari gunung disekitarnya yakni gunung Merapi dan Lawu. 


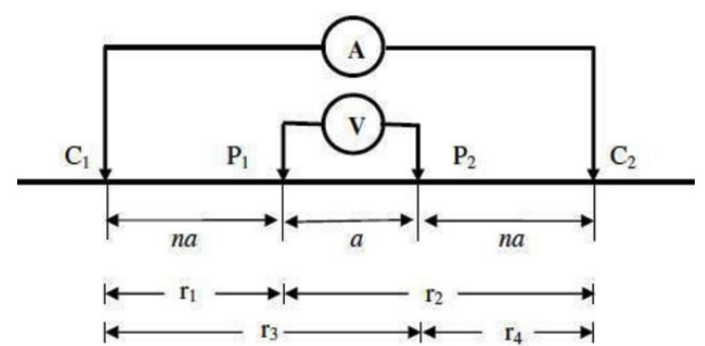

Gambar 1: Susunan elektroda pada konfigurasi WennerSchlumberger.

\section{Metode Geolistrik Resistivitas}

Prinsip pengukuran geolistrik yakni mengalirkan arus listrik ke dalam bumi melalui kontak dua elektroda arus $\left(\mathrm{C}_{1}\right.$ dan $\left.\mathrm{C}_{2}\right)$, kemudian diukur distribusi potensial $\left(\mathrm{P}_{1}\right.$ dan $\left.\mathrm{P}_{2}\right)$ yang dihasilkan. Resistivitas batuan bawah permukaan dapat dihitung dengan mengetahui besar arus yang dipancarkan melalui elektroda tersebut dan besar potensial yang dihasilkan. Keadaan bumi tersusun atas lapisan-lapisan yang memiliki nilai resistivitas beda-beda, sehingga nilai potensial yang terukur merupakan pengaruh lapisan-lapisan tersebut. Nilai resistivitas yang terukur ialah nilai resistivitas semu karena keadaan bumi yang berlapis-lapis bukan nilai satu lapisan saja. Nilai resistivitas semu dinyatakan dengan persamaan:

$$
\rho_{a}=K \frac{\Delta V}{I}
$$

dengan $\rho_{a}=$ resistivitas semu $(\Omega \mathrm{m}), \mathrm{K}=$ faktor geometri, $\mathrm{V}=$ tegangan (V), I = Arus (A).

Nilai K tiap survey geofisika berbeda-beda tergantung metode yang digunakan untuk pengukuran. Untuk metode konfigurasi Wenner-Schlumber yaitu:

$$
K=\operatorname{\pi an}(1+n)
$$

Metode konfigurasi Wenner-Schlumberger merupakan salah satu metode konfigurasi dalam geolistrik yang menggunakan dua buah elektroda yang bertindak sebagai arus dan dua buah elektroda bertindak sebagai potensial. Metode konfigurasi ini sebenarnya merupakan modifikasi dari bentuk konfigurasi Wenner dan konfigurasi Schlumberger, kedua konfigurasi ini dapat digunakan pada sistem konfigurasi yang menggunakan aturan spasi yang konstan dengan catatan faktor untuk konfigurasi ini adalah perbandingan jarak antara elektroda $\mathrm{C}_{1}-\mathrm{P}_{1}$ dan $\mathrm{C}_{2}-\mathrm{P}_{2}$ dengan spasi antara elektroda $\mathrm{P}_{1}-\mathrm{P}_{2}$. Dengan, a adalah jarak antara elektroda $\mathrm{P}_{1}-\mathrm{P}_{2}$ [3]. Seperti pada Gambar 1.

\section{METODOLOGI}

Peralatan yang digunakan dalam penelitian ini dapat dilihat di Gambar 2 adalah resistivity meter OYO model 2119C

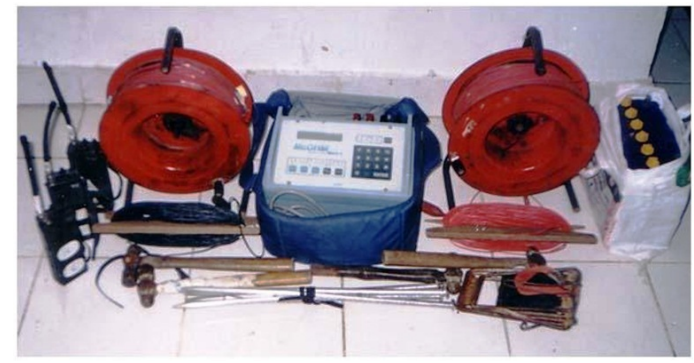

Gambar 2: Seperangkat Resistivity meter.

McOHM-EL, accumulator sebesar $12 \mathrm{~V}$, elektroda, dan multimeter. Penghubung instrumen antara resistivity meter dengan elektroda digunakan rol kabel. Peralatan pendukung lain yang digunakan dalam penelitian yakni rol meteran, Global Positioning System (GPS) Garmin Model II plus, dan Handy Talky.

Lokasi pengambilan data dilakukan di Desa Majasto dan Desa Ponowaren, Kecamatan Tawangsari, Kabupaten Sukoharjo. Pengambilan data geolistrik dilakukan sebanyak 3 lintasan dengan panjang lintasan 850, 600, dan 2400 meter, variasi jarak antar elektroda potensial 40 meter dan 50 meter, dan faktor pengali elektroda (n) 1 sampai 7. Arah lintasan pengambilan data seperti terlihat pada Gambar 3. Lintasan 1 sejauh 850 meter dengan arah pengambilan dari Barat ke Timur, Lintasan 2 sejauh 600 meter dengan arah pengambilan dari Utara ke Selatan. Lintasan 3 sejauh 2400 meter dengan arah pengambilan dari Barat ke Timur.

\section{HASIL DAN PEMBAHASAN}

Pengolahan data resistivitas semu yang diperoleh dari hasil pengukuran dilakukan dengan menggunakan software Res2Dinv sehingga diperoleh peta lateral 2 dimensi.

\section{Lintasan Pertama}

Lintasan pertama diambil pada koordinat $07^{\circ} 42^{\prime} 36.3^{\prime \prime} \mathrm{LS}$ dan $110^{\circ} 46^{\prime} 41.1$ " BT dengan elevasi 118 meter dan arah pengambilan data dari arah Barat menuju Timur. Panjang lintasan pengambilan data yaitu 850 meter dengan jarak antar elektroda potensial 50 meter dan faktor pengali elektroda arus (n) 1 sampai 7 diperoleh kedalaman hingga 134 meter dengan kesalahan iterasi $8,7 \%$.

\section{Lintasan Kedua}

Lintasan kedua diambil pada koordinat $07^{\circ} 42^{\prime} 27.1^{\prime \prime}$ LS dan $110^{\circ} 46^{\prime} 49.0^{\prime \prime}$ BT dengan elevasi 117 meter dan arah pengambilan data dari arah Utara menuju Selatan. Panjang lintasan pengambilan data yaitu 600 meter dengan jarak antar elektroda potensial 40 meter dan faktor pengali elektroda arus (n) 1 sampai 6 diperoleh kedalaman hingga 107 meter dengan kesalahan iterasi $6,8 \%$. 


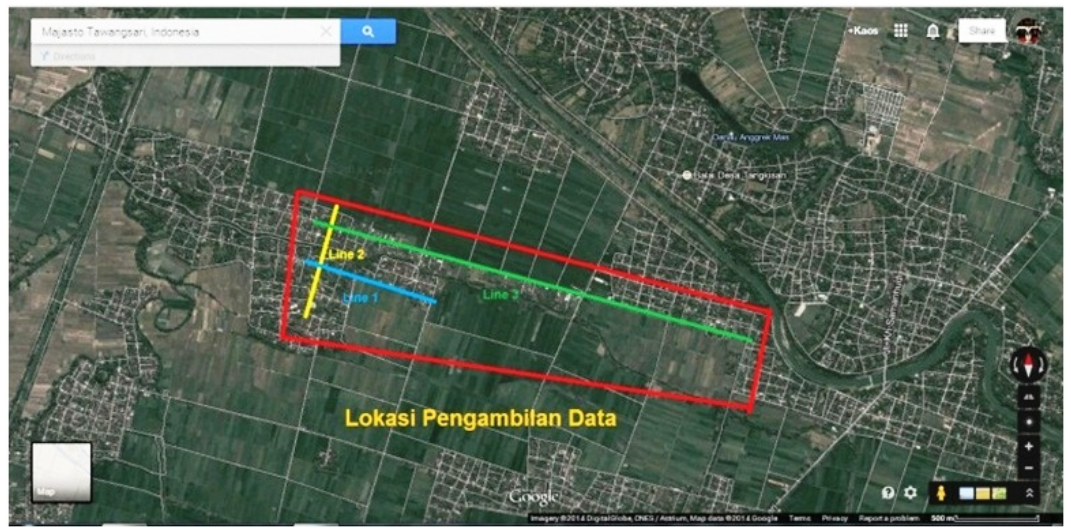

Gambar 3: Lokasi Penelitian.

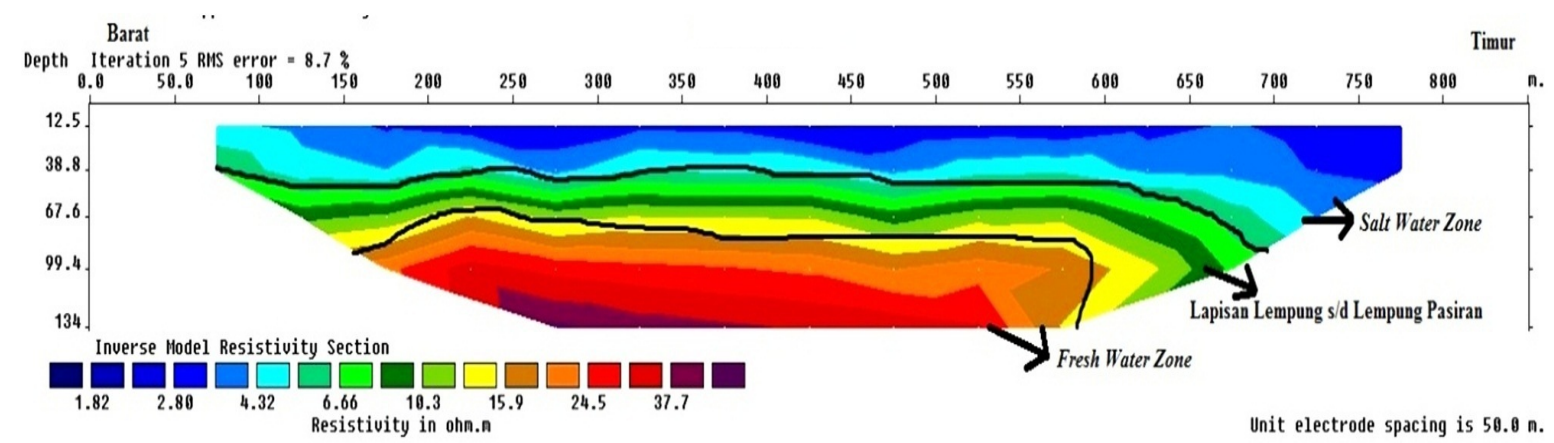

(a) Lintasan Pertama

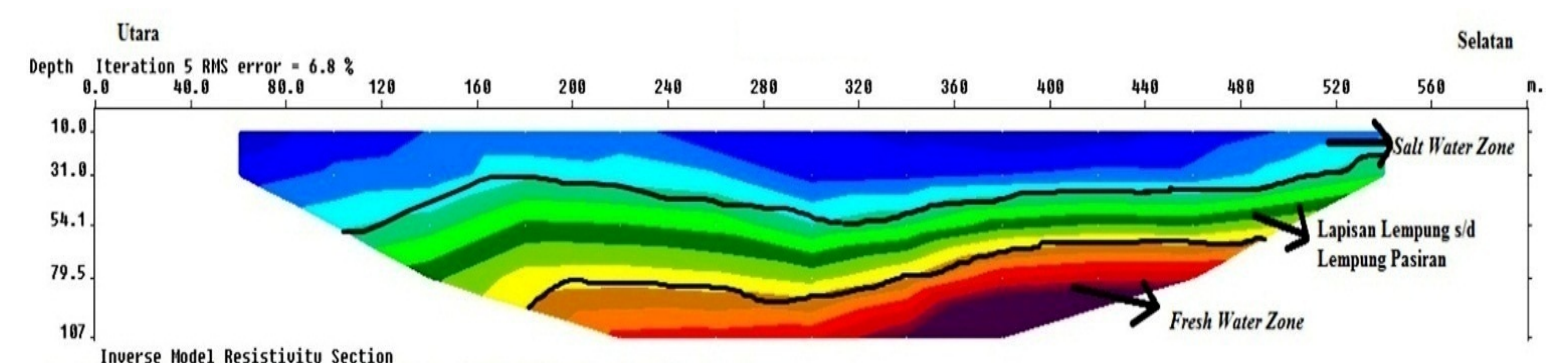

Inverse Model Resistivity Section

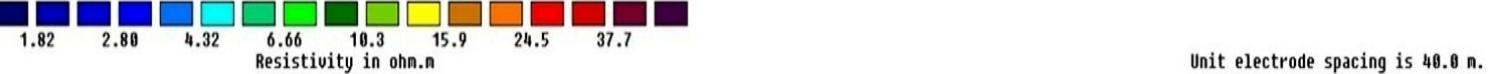

(b) Lintasan Kedua

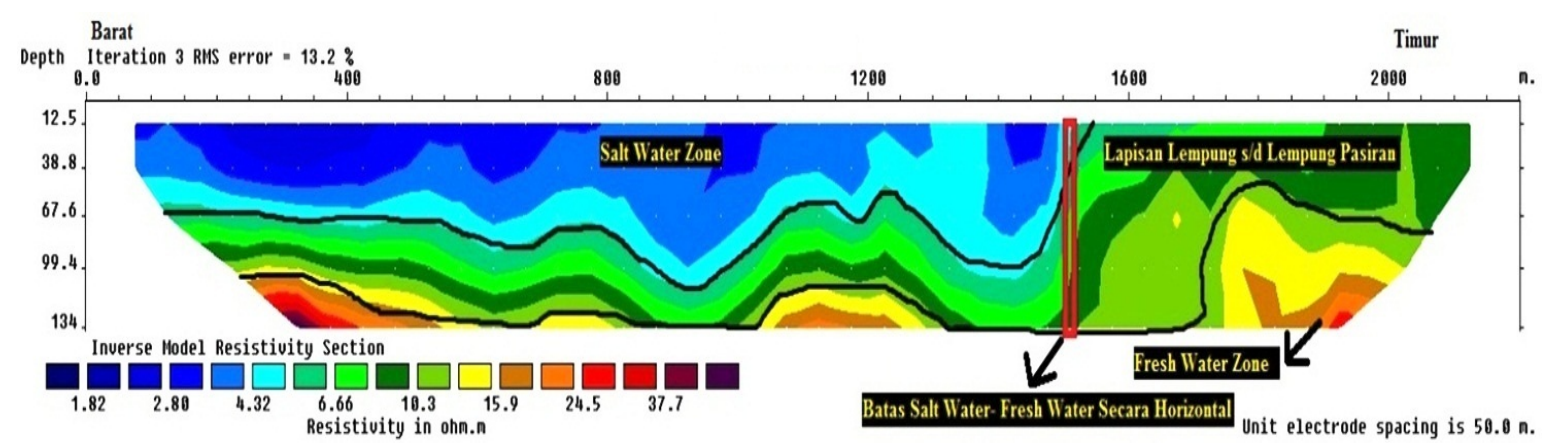

(c) Lintasan Ketiga

Gambar 4: Hasil Pengolahan ketiga lintasan. 


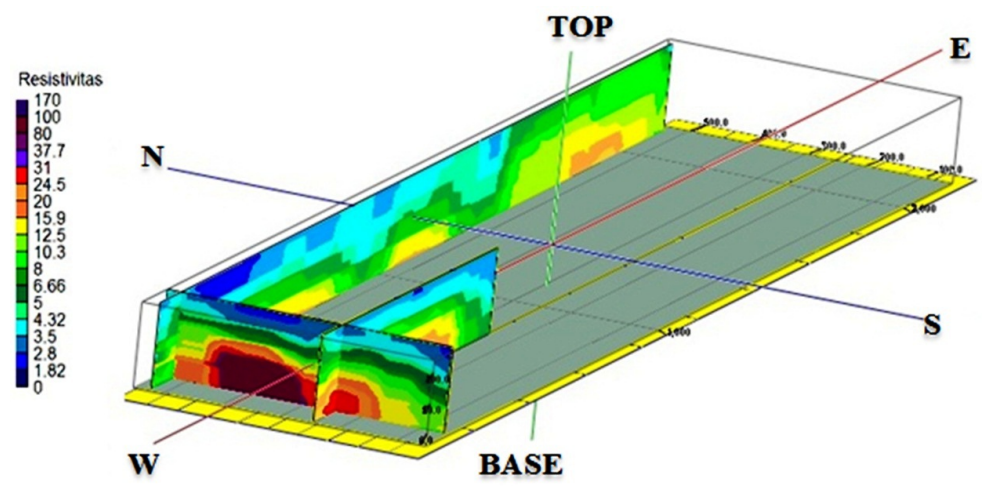

Gambar 5: Hasil Pengolahan Semua Lintasan.

\section{Lintasan Ketiga}

Lintasan ketiga diambil pada koordinat $07^{\circ} 42^{\prime} 28.8^{\prime \prime}$ LS dan $110^{\circ} 46^{\prime} 45.2^{\prime \prime}$ BT dengan elevasi 117 meter dan arah pengambilan data dari arah Barat menuju Timur. Panjang lintasan pengambilan data yaitu 2400 meter dengan jarak antar elektroda potensial 50 meter dan faktor pengali elektroda arus (n) 1 sampai 7 diperoleh kedalaman hingga 134 meter dengan kesalahan iterasi $13,5 \%$. Hasil pengolahan ketiga lintasan dapat dilihat pada Gambar 4.

\section{Pembahasan}

Hasil dari pengolahan data dari lintasan pertama dan kedua dapat diambil kesimpulan bahwa disetiap lintasan diperoleh batasan antara salt water-fresh water. Daerah yang diinterpretasikan sebagai daerah salt water terletak dekat dengan permukaan tanah dengan nilai resistivitas $1,82 \Omega$ m sampai 4,32 $\Omega \mathrm{m}$ terletak disepanjang permukaan lintasan dengan kedalam \pm 50 meter, kecuali pada lintasan ketiga setelah bentang 1500 meter ke timur diindikasikan daerah ini merupakan batas antara salt water-fresh water secara horizontal dengan adanya kenaikan nilai resistivitas di daerah dekat permukaan tanah.

Data yang ditunjukkan di lapangan bahwa sebagian besar sumur warga air sumurnya terindikasi salt water dengan kedalaman dari sumur warga tersebut berkisar antara 10 sampai 15 meter, sedangkan secara literatur nilai resistivitas batuan sedimen yang mengandung salt water yaitu 1-7 $\Omega \mathrm{m}$ [4]. Pada lapisan salt water dan fresh water terdapat lapisan penyekat diantara keduanya ialah lapisan lempung sampai lempung pasiran. Lempung memiliki nilai porositas $45-55 \%$ dan nilai permeabelitas yang rendah yaitu $0,0004 \mathrm{~m} / \mathrm{hari}$ [5].
Lapisan lempung ini bukan akuifer yang baik. Adanya sekat pembatas oleh lapisan lempung sampai lempung pasiran ini diduga bahwa airtanah yang berada di bawah lapisan itu merupakan fresh water. Daerah yang diindikasikan sebagai daerah fresh water memiliki rentang 24,5 $\Omega \mathrm{m}$ sampai 37,7 $\Omega \mathrm{m}$ diperoleh di kedalaman \pm 100 meter. Dengan dasar nilai resistivitas batuan sedimen yang mengandung fresh water yaitu $25 \Omega \mathrm{m}$ sampai $200 \Omega \mathrm{m}$ [4]. Hasil pengolahan semua lintasan dapat dilihat seperti Gambar 5.

\section{SIMPULAN}

Berdasarkan hasil pengolahan dan interpretasi dapat diambil kesimpulan bahwa pada Desa Majasto dan Desa Ponowaren, Kecamatan Tawangsari, Kabupaten Sukoharjo sebagian besar airtanah pada lapisan dekat permukaan tanah ialah salt water hal ini karena pada lapisan yang dekat permukaan tanah dengan kedalaman antara 0 sampai 50 meter nilai resistivitasnya $1,82 \Omega \mathrm{m}$ sampai $4,32 \Omega \mathrm{m}$. Sehingga apabila warga ingin menggali atau mengebor sumur pada kedalaman tersebut dapat dipastikan akan menemui daerah salt water hal ini sesuai dengan data yang di lapangan bahwa sebagian besar sumur warga dengan kedalaman 10 sampai 15 meter terindikasi salt water. Sedangkan daerah yang terinterpretasi sebagai daerah yang mengandung fresh water terletak di kedalaman lebih dari 100 meter.Kemudian untuk daerah yang mengandung fresh water secara horizontal terletak di sebelah Timur Desa Majasto. Dimana nilai resistivitas di lapisan dekat permukaan tanah nilai resistivitasnya diatas $6,66 \Omega \mathrm{m}$ sehingga dapat disimpulkan bahwa kadar salt water di daerah tersebut berkurang.
[1] T. Indrawati, Pembangunan Jaringan Pipanisasi Majasto ditargetkan selesai Oktober (15 Agustus 2010. http://www.solopos.com/2010/08/15/pembangunan-jaringanpipanisasi-majasto-ditarget-selesai-oktober-41150(2010)).

[2] G. Handayani, dan Ngadimin, JMS, April, 6(1), 43-53 (2001).

[3] A. Satriani, A. Loperte, M. Proto, Electrical Resistivity Tomography For Coastal Salt Water Intrusion Characterization Along The Ionian Coast Of Basilicata Region (Southern Italy), Fif- teenth International Water Technology Conference (IWTC-15), Alexandria, Egypt, 2011.

[4] A.A. Ravindran, N. Ramanujam, R. Sudarsan, Tamilnadu. Water, April, 5(1), 1-11 (2013).

[5] T. Santoso, N. Priyantari, dan P. Hiskiawan, Berkala Sainstek, 1(1), 17-19 (2013). 